\title{
SEVEN WHITMAN LETTERS
}

\author{
BY ORAL SUMNER COAD
}

AgaIN DR. Coad has taken the time to examine some new acquisitions of manuscripts by Walt Whitman and to give us an account of their place in the life of the poet. Readers of the JOUR NaL, and, indeed, students of American literature in general, will not need a further introduction to him and to his work.

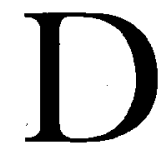

URING the past few years the Rutgers University Library has acquired by purchase seven letters written by Walt Whitman near the end of his life. They are addressed to William Sloane Kennedy, an active literary man of the time, whose acquaintance with the poet, begun in 1880 , soon ripened into close friendship. So far as I know, these letters have never been published in their entirety, although excerpts from two or three have appeared. There is not, it must be admitted, anything startling in them, but for their minor disclosures and in some cases for their reaffirmation of Whitman's poetic faith they are perhaps worth reproducing here.

\section{I}

328 Mickle St:

Camden $\mathrm{N} \mathrm{J}$

May 24'85

\section{Dear friend}

The long MS ["Poet as a Craftsman" inserted above the line in Kennedy's handwriting] you sent me some months since is all right $\mathcal{E}^{2}$ I will return it to you forthwith-The whole drift of it is lofty, subtle $\mathcal{E}^{2}$ true-I would not put it out by itselfSuch things never strike in so well in the abstract, as in illustration of some definite personal, critical concrete thing.- - I suggest to you a criticism on Tennyson and Walt Whitman (or if you prefer on Victor Hugo, $T$ and $W W$ ) where they should be work'd in-What think you?

\section{W W}

This letter gives some slight insight into Whitman's habit of thought in his insistence that abstractions are effective only when 
allied to something definite, personal, and concrete. Such is the nature of his own critical writing, the soundness and acuteness of which, incidentally, have not always been given due recognition. Such too is the nature of his general philosophy, which springs from his absorption in human personality-that is, from his invariable practice of thinking in terms of men and women. His suggestions for the specific poets to be used in illustration of Kennedy's abstract ideas perhaps indicate his conception of the company he kept among his contemporaries in respect to literary eminence, however wide the gulf that separated them in theme and technique.

Apparently the effect of this letter was to cause Kennedy to revise his manuscript according to his friend's recommendation, for The Poet as a Craftsman, published in pamphlet form a few months later, is a defense of technical freedom in poetry, in which Whitman is cited at length as the chief American exemplar of this principle and is compared with Hugo, who broke the shackles of French classicism. But Kennedy adds that Whitman's reform is as far in advance of Hugo's as Hugo's was in advance of the tradition against which he rebelled.

328 Mickle street

Camden New Jersey

Dec. 2 '85 noon

\section{Dear W S K}

Your "the Poet as a Craftsman" seems the best statement possible of the modern scientific American point of view-as it certainly is the highest $\mathcal{E}$ deepest (complimentary) statement of my theory $\mathcal{E}^{2}$ practise in $\mathrm{L}$ of $\mathrm{G}-\mathrm{I}$ only rec'd it an hour or so ago-so reserve most of what I have to say for another letter.If you have them to spare, can you send copies by mail to following?

[He then lists these men, with their addresses: William Michael Rossetti, Edward Dowden, T. W. Rolleston, Alfred Tennyson, J. Addington Symonds, Edward Carpenter, Ernest Rhys, Karl Knortz, G. C. Macaulay, Richard Watson Gilder, William D. O'Connor, John Burroughs, Edmund Stedman, R. M. Bucke, James Knowles.] 
-if you can send these do it at your leisure-only let me know if you cannot send

-I am getting along middling well. Eyesight improved again ab't as well as of late years-Walking power quite gone-Spirits buoyant $\mathcal{E}^{2}$ hearty-The December sun is shining out wistfully as I finish, E I am going out in my wagon, for a two or three hours drive-

\section{WaLt Whitman}

The Poet as a Craftsman, which must have been issued late in I 885 although dated I 886, naturally gave Whitman much satisfaction as convincing evidence of understanding discipleship on Kennedy's part. ${ }^{1}$

The list of men to receive copies of the pamphlet is an interesting roster of some of the poet's most distinguished friends and admirers on both sides of the Atlantic.

Whitman's buoyancy and heartiness, his delight in the sunshine, and his eagerness for a spin in that buggy which, with a horse, his friends had recently given him and in which he was fond of driving too fast, all bear testimony to a spirit that paralysis and his other physical ills could not quench. The unconventionality of the writer is suggested by the color-scheme of this letter: it is written partly with a purple pencil, partly with black ink, and partly with red.

\section{I I}

Have look'd over the whole MS. pretty well-with an eye to correction of dates $\mathcal{E}$ statistics-have a very few times made my own comments $\mathcal{E}$ suggestions (from my own point of view, or feeling, or knowledge) - you follow the suggestions or not, as you think best-

The handwriting of this undated and unsigned note seems to indicate a time not far from the end of the writer's life. It bears this identification: "(Scrawl from Walt respecting MS of my book on him W.S.K.)." The book, unquestionably Reminiscences of Walt Whitman, was not published until 1896 and indeed contains an account

${ }^{1}$ At the head of the letter Kennedy has written: "This letter relates to what now forms a portion of chap. III of my 'Walt Whitman.' " A comparison shows that Part III of Reminiscences of Walt Whitman, entitled "The Style of Leaves of Grass," is an expansion of this pamphlet. 
of the poet's death and funeral, but it apparently existed almost in its entirety before its subject died. The interest here is in the evidence that Whitman corrected and to a slight degree revised the manuscript, as he had already done on a much more elaborate scale in the case of another friend's book about him, Dr. Richard Maurice Bucke's Walt Whitman (1883), which, as a matter of fact, he partly wrote. Whether Kennedy accepted the emendations I do not know, but his deep respect for the poet would lead one to suppose that he did.

\section{V}

\section{Camden Feb: I I '9 I near noon}

Bright sunlight out - Am feeling fairly — send you a couple slips of the Dutch piece-it is the best thing of its kind yet-H T's paper ${ }^{2}$ will be out in four days $\mathcal{E}^{2}$ you can have as many as you want or more slips either-Yes Ernest Rhys ${ }^{3}$ was married in London early last month-If I get letter or details I will send you-Dr B[ucke] is recovered fully-is well-I see James Redpath ${ }^{4}$ is dead in $\mathrm{N} \mathrm{Y}-\mathrm{Y}^{\prime} \mathrm{r}$ letter

\section{rec'd-WALT WHITMAN}

The "Dutch piece" was an article by Kennedy, called "The Dutch Traits of Walt Whitman," which first appeared in The Conservator of February, I 89r, and was later included in In Re Walt Whitman ( 1893 ), edited by Horace Traubel, R. M. Bucke, and T. B. Harned. It is interesting to compare this letter as Whitman wrote it with an excerpt from it that Kennedy printed in his Reminiscences of Walt Whitman (p. 67). There, following a custom all too common with editors and biographers, he made Whitman say, not what he actually said, but what he should have said. This is Kennedy's improved version:

Feb. I I, '9 г.

Send you a couple of slips of [your article] the Dutch piece. I like it well. It is the best thing of its kind yet. I have added a few trivialities.

2 Undoubtedly "Walt Whitman: Poet, Philosopher and Man," by Horace Traubel, which appeared in Lippincott's Magazine, March, I891.

${ }^{3}$ Ernest Rhys was a British author and an admirer of Whitman.

${ }^{4}$ James Redpath, founder of the well-known lecture bureau, was one of the poet's friends. 
Presumably Whitman did like it well, as Kennedy caused him to declare in italics, but he failed to say so in his letter. The other interpolation, "I have added a few trivialities," becomes a kind of confession on Kennedy's part that the essay as published contained some changes from the pen of its subject.

This letter and the remaining ones make increasing reference to the illness from which Whitman suffered during the last months of his life, but they show how his thoughts were able to rise above it and to dwell rather on his friends and his work.

\section{V}

Camden Evn'g: May 27 '9I

Pretty bad gastric bladder $\mathcal{E}^{2}$ catarrhal times continued but might be worse-bowel movement today. first in a week-sit up most of the time-over third of the time deathly weak, cannot rise-splendid short autograph word f'm Tennyson anent of birth day-have sent "Good-Bye" to [Hamlin] Garland(he sent \$5. I sent two [copies?]) - the preparatory all-enclosing continual theory of $\mathrm{L}$ of $\mathrm{G}$. is, myself, opening myself first to the countless techniques, traditions, samples, items, knowledges $\mathcal{E}^{2} c$ : $\mathcal{E}^{2} c$ : $\mathcal{E}^{2} c$ : as a fund $\mathcal{F}^{2}$ interim battery, magazine $\mathcal{F}^{2}$ identity: sphere, nothing too small to be despised all welcom'd to be digested $\mathcal{E}$ ' formulated by my own living personal emotionality, wh-shapes $\mathcal{E}^{2}$ stamps the L. birth marks f'm first to last, more than any book known-(it is the volume of human personality down below every thing else)-The screws have been turn'd down on the clef of "Good-Bye," to keep things low, yet garrulous, perhaps sometimes irascible (Lear like) but quite a different atmosphere f'm the preceding (while the same subject continued) - I have been a little afraid of monotony but the trend of the invisible wind is mainly the same-all thiskeep all this for your own use

WW

This letter is of some significance because it reiterates the conception of his poetic theme and purpose that Whitman expressed elsewhere in somewhat different words and that he adhered to throughout his writing career. Beginning with "Song of Myself" ( 1855 ) his poetry is a complete exemplification of the theory here 
stated that his theme should be himself as a representative man, in whom nothing is too small (or too unworthy) to be included. Thus, he felt, he got at the ground plan of human personality as few authors had done. This principle, practiced for many years, perhaps had its fullest formulation in "A Backward Glance O'er Travel'd Roads" (r888), where he wrote:

After years of those [i. e., the conventional] aims and pursuits, I found myself remaining possess'd, at the age of thirty-one to thirty-three, with a special desire and conviction. Or rather, to be quite exact, a desire that had been flitting through my previous life, or hovering on the flanks, mostly indefinite hitherto, had steadily advanced to the front, defined itself, and finally dominated everything else. This was a feeling or ambition to articulate and faithfully express in literary or poetic form, and uncompromisingly, my own physical, emotional, moral, intellectual, and aesthetic Personality, in the midst of, and tallying, the momentous spirit and facts of its immediate days, and of current America - and to exploit that Personality, identified with place and date, in a far more candid and comprehensive sense than any hitherto poem or book.

"Leaves of Grass" indeed (I cannot too often reiterate) has mainly been the outcropping of my own emotional and other personal nature-an attempt, from first to last, to put a Person, a human being (myself, in the latter half of the Nineteenth Century, in America,) freely, fully and truly on record. I could not find any similar personal record in current literature that satisfied me.

And again a few months after writing the above letter he returned to the theme in a brief statement published in Lippincott's Magazine, August, I89I, under the title, "Walt Whitman's Last":

The theory of my "Leaves of Grass" as a composition of verses has been from first to last, (if I am to give impromptu a hint of the spinal marrow of the business, and sign it with my name,) to thoroughly possess the mind, memory, cognizance of the author himself, with everything beforehand-a full armory of concrete actualities, observations, humanity, past poems, bal- 
lads, facts, technique, war and peace, politics, North and South, East and West, nothing too large or too small, the sciences as far as possible - and above all America and the present-after and out of which the subject of the poem, long or short, has been invariably turned over to his Emotionality, even Personality, to be shaped thence; and emerges strictly therefrom, with all its merits and demerits on its head. Every page of my poetic or attempt at poetic utterance therefore smacks of the living physical identity, date, environment, individuality, probably beyond anything known, and in a style often offensive to the conventions.

This conception, which Whitman rightly called "the preparatory all-enclosing continual theory" of Leaves of Grass, is suggestively summed up in our letter in the words, "it is the volume of human personality down below every thing else."

The "Good-Bye" to which reference is made is Good-Bye, My Fancy (I89I), the last volume of additions to his work that Whitman made. It is a slender collection of prose and poetry, low-keyed and garrulous, as he describes it, though not strikingly "Lear like." A similar description of this book is included in "Walt Whitman's Last," following the paragraph on Leaves of Grass quoted above:

This new last cluster, "Good-By my Fancy" follows suit, and yet with a difference. The clef is here changed to its lowest, and the little book is a lot of tremolos about old age, death, and faith. The physical just lingers, but almost vanishes. The book is garrulous, irascible (like old Lear) and has various breaks and even tricks to avoid monotony.

Here the idea contained in the letter is expressed with more finish and detail, but the finely suggestive comparison that Whitman implies between the trend of his work and that of the invisible wind is found only in the letter.

V I

noon-just refresh'd by a mug of iced buttermilk this hot day

Camden July 7 '9 I

Yr's rec'd this forenoon always welcomed. Fine weather, sunny, perfect, now the fourth day. Quite a hearty breakfast, 
oysters, (good here)-Warry [Warren Fritzinger, his nurse] got me up $\mathcal{E}$ dress'd, $\mathcal{F}^{2}$ has gone off to $\mathrm{N}$ Y to see Dr Bucke. (W returns this evn'g.) Dr B goes over in the Britannic $71 / 2 \mathrm{a} \mathrm{m}$ July 8. to be gone till end of Aug:-will go to see Tennysonwill see a cluster of g't $L$ of $G$. friends in Bolton, Lancashire.(Dr Johnston $\mathcal{E}^{5} \mathrm{~J} \mathrm{~W}$ Wallace leaders ${ }^{5}$ ) - I am fairly to-day - the birth-day rep't is to be printed (article by Traubel) in Lippincott's August-gives a very good acc't of all- (of course I did not attempt a line of $L$ of $G$ ) - amazed myself by keeping up three hours, chattering, interpolating, drinking champagne $\mathcal{E}^{2}$ moderately eating-enjoyed it all muchly-most of the time continuing these days sitting here in big chair aloneKeep pretty good spirits-horribly feeble extreme inertia cannot move across the room without help,-right arm, power good - nights fair- - a stout massage every evn'g — eat blackberriesLove to the dear wife $\mathcal{E}$ write often as convenient-yes I fancy Eliz: $\mathrm{P}$ Gould ${ }^{6}$ is a noble woman

\section{WALT W HITMAN $^{7}$}

Kennedy printed about a third of this letter in Reminiscences ( $\mathrm{p}$. 68), but he omitted the most interesting part. Except for the iced buttermilk he left out all the evidence of Whitman's hearty pleasure in the good things of life and in comradeship even in his decrepit old age.

The party to celebrate the poet's seventy-second birthday, to which allusion is made, was held in his own home and was attended by thirty-two guests. Traubel's account of it in Lippincott's Magazine was a verbatim report of much of the talk of the evening, especially Whitman's, and of the many letters sent him in honor of the occasion.

${ }^{5}$ John Johnston and J. W. Wallace wrote Visits to Walt Whitman in ${ }_{1} 890-189 x$ by Two Lancashire Friends (London, I917).

${ }^{6}$ Elizabeth Porter Gould brought out Gems from Walt Whitman in 1889 , including in the book an article of hers concerning his work among the soldiers. She also wrote Anne Gilchrist and Walt Whitman (1900).

7 This letter and the previous one are written on the stationery that Whitman commonly used at this time-roughly cut, light orange paper with these words printed sidewise in the margin: "From the Boston Eve'g Transcript, May 7, '9r.-The Epictetus saying, as given by Walt Whitman in his own quite utterly dilapidated physical case, is, a slittle spark of soul dragging a great lummux of corpse-body clumsily to and fro around." " 


\section{Camden July i 8 '9 I}

\section{I I}

Bad days $\xi$ nights with me-neuralgic sick headache in addition to other ails-Keep up $\mathcal{E}^{\mathcal{F}}$ was out yesterday to my tomb in Harleigh Cemetery (will send you a sort of photo soon)-Dr Bucke has arrived in Eng: $\mathcal{E}$ is with the friends at Bolton (cablegram yesterday) - the enc': letters are lately f'm Bolton - Sarrazin ${ }^{8}$ came back to Paris very sick, but is grown better$\mathrm{H}$ Traubel goes on to Wash'n to see Mrs: O'C E' others anent of a book cont'g O'C's splendid life-saving sketches ${ }^{9}$ ( $\mathrm{f}^{\prime} \mathrm{m}$ wrecks) - hot weather here five days-am feeling it badly, but getting along better than you w'd think-Love to you $\mathcal{E}^{\circ}$ frau

\section{WaLt WhitMan}

This note was written on the inside of a used envelope, a familiar and thrifty practice of Whitman's. The allusion to letters from Bolton indicates that his English admirers kept in touch with him in these last months, to his obvious pleasure.

These seven letters to Kennedy, as already remarked, add little if anything to our previous knowledge of Whitman. But they do reemphasize certain familiar traits of the man, especially his preoccupation with his great book and with his fame as the author thereof, his warm attachment to his friends, and his fortitude in the face of physical suffering.

${ }^{8}$ Gabriel Sarrazin was a French critic and admirer of Whitman.

9 These sketches were the work of William Douglas O'Connor (who died in 1889), Whitman's fieriest champion, as his famous pamphlet, The Good Gray Poet, attests. During the last years of his life he was Assistant General Superintendent of the United States Life-Saving Service (now a part of the Coast Guard). Since, as a youth, he had studied to be an artist, it is probable that the sketches were drawings or paintings of life-saving scenes. That $\mathrm{O}^{\prime}$ Connor made such pictures is hinted at in the introduction to Heroes of the Storm (Boston and New York, 1904), a collection of excerpts made by Charles W. Eldridge from those parts of the annual reports of the Service in which O'Connor described with graphic power the more dramatic incidents in the work of the life-savers. The introduction by Sumner I. Kimball, Superintendent of the Service, refers to O'Connor's gift for painting a picture clearly "either with words or color." Nothing seems to have come of Traubel's efforts to make a book of the sketches. 